University of Cincinnati College of Law

University of Cincinnati College of Law Scholarship and

Publications

2022

Recognition and Enforcement of Foreign Judgments in American

Courts and the Limits of the Law Market Model

Michael E. Solimine

Follow this and additional works at: https://scholarship.law.uc.edu/fac_pubs

Part of the Conflict of Laws Commons, Contracts Commons, and the International Law Commons 


\title{
RECOGNITION AND ENFORCEMENT OF FOREIGN JUDGMENTS IN AMERICAN COURTS AND THE LIMITS OF THE LAW MARKET MODEL
}

\author{
Michael E. Solimine*
}

\begin{abstract}
The law market model posits that the most appropriate resolution of choiceof-law disputes in private international law is to permit individuals to choose ex ante the law that applies to them. This is contrasted to the public law model where courts choose law based on the perceived interests of, or the parties' connections with, the states or nations involved. The law market model envisions that consumer choice will lead to optimal competition among jurisdictions to supply the most efficient law. This model has influenced the rise of party autonomy, most notably in the widespread enforcement of many contractual choice-of-law and forum-selection clauses. One area that the model has had little influence on is the enforcement of foreign judgments. In the United States, judgments from other countries face higher hurdles in obtaining recognition and enforcement, as compared to judgments issued by courts of sister states. There has been little discussion in the law market literature of the possibility of ex ante contractually waiving these hurdles, or of choosing the law of states that make it easier to enforce foreign judgments. This reticence appears to be based in part on the assumption that state law on such recognition is mandatory and non-waivable, and that such law reflects the sovereign interests of states. Revisiting this regime through the lens of the law market model suggests that courts and public policymakers should permit parties, within broad limits, to contractually waive or select the law on judgment recognition, as they are permitted to do with other areas of law.
\end{abstract}

\section{INTRODUCTION}

The law market model, whether conceived as applying to one nation or state, or to many nations internationally, posits that the most appropriate resolution of choice-of-law disputes in private international law is to empower the parties themselves. That is, the model argues that individuals in contractual or other legal relationships should be empowered to choose the law ex ante that applies to their

\footnotetext{
Donald P. Klekamp Professor of Law, University of Cincinnati College of Law. Thanks to Ronald Brand, Jacob Cogan, John Coyle, Celia Fassberg, Michael Karayanni, Dan Klerman, Erin O'Hara O'Connor, Greg Shill, and Chris Whytock for helpful discussions and comments on a previous draft of this Article, and on the issues raised in this Article. A previous draft was presented at the conference on The Global Law Market: New Frontiers for Economic and Empirical Analysis of Private International Law, January 2021, sponsored by the Cegla Center for Interdisciplinary Research of the Law, and the Buchmann Faculty of Law, Tel Aviv University. Cite as: Michael E. Solimine, Recognition and Enforcement of Foreign Judgements in American Courts and the Limits of the Law Market Model, 23 Theoretical Inquiries L. 97 (2022).
} 
relationship. The law market model envisions that consumer choice will lead to a healthy competition among jurisdictions to attract consumers, which will lead to welfare gains by generating more efficient laws. In contrast, the familiar public law model relies, in various formulations, on legislative bodies or courts choosing law based on the perceived interests of the jurisdictions involved in or affected by a multistate dispute, frequently accompanied by an implicit or explicit weighing of those interests.

Both in the United States and internationally, the law market model has had significant success regarding conflicts arising from legislative or judicial jurisdiction. This is especially true regarding the now-widespread enforcement of contractual choice-of-law and forum-selection clauses, at least within broad limits. One area where it has had little apparent influence, however, is the recognition and enforcement of foreign judgments in the courts of the United States. Due to the Full Faith and Credit Clause of the U.S. Constitution, American courts must, with few exceptions, recognize and enforce judgments from the courts of other American states. That clause, in contrast, does not apply to judgments from the courts of other nations, and the conventional wisdom is that state law makes it more difficult to enforce such judgments in American courts, as compared to judgments from American courts.

Either way, though, there have apparently been very few efforts to seek judicial enforcement of choice-of-law or forum-selection clauses to ex ante select or waive the recognition and enforcement regime for judgments. The literature on national or global law markets has said relatively little about this possibility, and this Article aims to fill that gap, focusing on foreign judgment enforcement in the courts of the United States. The topic is particularly timely since some empirical studies suggest that some American courts are increasingly being asked to enforce foreign judgments. ${ }^{1}$

Part I of the Article addresses the American law of the recognition and enforcement of foreign judgments, that is, those entered in the courts of other states and countries, and the dichotomy of enforcement between judgments from another state, and those from another nation. Part II turns toward the law market model and addresses how little that model has heretofore impacted judgment recognition. There are some cases which suggest that the model can be applied on this topic, but they are clearly the exception, not the rule. Part III descriptively explores reasons for the lack of impact of the law market model in this context. The principal reason is that the federal law on sister-state judgement recognition, and state law on recognition of judgments from other countries, is considered mandatory and non-waivable. This seems to have widespread acceptance in the legal community, despite the fact that the legislation in question does not have mandatory language. Moreover, political and cultural norms appear to play a role in the reticence of the American legal community to permit waiver or contractual modification of state judgment

1 See, e.g., Kevin M. Clermont \& Theodore Eisenberg, Xenophilia or Xenophobia in U.S. Courts? Before and After 9/11, 4 J. EMPIRICAL Leg. STUD. 441, 459-64 (2007); Marcus S. Quintanilla \& Christopher A. Whytock, The New Multipolarity in Transnational Litigation: Foreign Courts, Foreign Judgments, and Foreign Law, 18 Sw. J. INT'L L. 31, 33-35 (2012). 
recognition laws. Finally, Part IV normatively addresses whether the law market model should be used in this context, concluding that parties should be able to ex ante choose enforcement regimes, at least within broad limits, just as they can do for many types of substantive and other procedural law. Examples where ex-ante choice would likely be inappropriate could include contractual relationships where there is presumed or acknowledged asymmetry in information or bargaining power, or tort actions where there is no prior legal relationship at all. These considerations illustrate the promise and limits of broader application of the law market model.

\section{RECOGNITION AND ENFORCEMENT OF Foreign Judgments in American Courts}

Even summarizing the law of recognition and enforcement of foreign judgments in American courts is not without its challenges, in no small part given the amalgam of federal and state law that governs the topic. But for purposes of this Article, the task is fairly clear. Start with the concepts of recognition and enforcement. The former means when an American court gives preclusive effect to the claims or issues resolved in litigation concluded in another state or country. In contrast, the latter means when a state uses its coercive power to compel a defendant to satisfy a judgment, typically one for money, entered into by a court of another jurisdiction. ${ }^{2}$ This Article will mainly focus on the latter term but both terms will be used for convenience.

The law governing the recognition of judgments from American courts by federal or state courts of one of the American states is fairly straightforward. The Full Faith and Credit Clause of the U.S. Constitution, ${ }^{3}$ augmented by the Full Faith and Credit Act passed by Congress, ${ }^{4}$ requires that state and federal courts enforce judgments from other state or federal courts. This mandate is subject to a few exceptions. The judgment need not be enforced if the rendering court lacked personal or subject matter jurisdiction, or if the defendant failed to get proper notice, though those objections fail if the rendering court itself considered and rejected them. Similarly and importantly, there is no exception if recognition would violate a public policy of the state where enforcement is sought. ${ }^{5}$

Thus, there are relatively few barriers to the enforcement of a sister-state judgment. In contrast, it is widely acknowledged that there are more potential barriers to the enforcement of a judgment from the court of another nation. ${ }^{6}$ The principal reason for this distinction is that the recognition of foreign judgments is mainly governed

2 Gary B. Born \& Peter A. Rutledge, International Civil Litigation in United States Courts 1068 (6th Cir. 2018).

U.S. Const. art. IV, $\$ 1$.

28 U.S.C. $\$ 1738$.

BORN \& RutLEDGE, supra note 2, at 1068-69.

Id. at 1146; Lea Brilmayer et Al., Conflict of Laws 545 (8th ed. 2020). One way to work around this distinction is to "launder" a foreign judgment by having it recognized in one state court, and then enforcing it in another state that would not have recognized it in the first instance. See Gregory H. Shill, 
by the law of the American federal states. The Full Faith and Credit Clause by its terms does not apply to foreign judgments, and the United States is not a party to a treaty or other international agreement regarding recognition of judgments. ${ }^{7}$ It has not been for lack of effort; for several decades there have been significant efforts to draft an acceptable multilateral judgments convention, most notably the Hague Choice of Court Agreements Convention of 2005. ${ }^{8}$ But the United States and most other countries have not ratified that convention. ${ }^{9}$

This void has been filled by federal common law and state law. The starting point are the guidelines set out by the venerable U.S. Supreme Court decision of Hilton $v$. Guyot,${ }^{10}$ which focused on notions of international comity to guide the decision of an American court to enforce a foreign judgment. Those factors included whether there was an opportunity for full and fair litigation before an impartial tribunal in the foreign country, and whether the country would as a matter of reciprocity enforce a judgment from an American court. ${ }^{11}$ Despite many subsequent developments concerning foreign judgment enforcement, Hilton v. Guyot continues to have significant influence in American courts. ${ }^{12}$

While federal courts, ${ }^{13}$ and some state courts, still follow a version of the comity approach of Hilton, over thirty states have enacted one or more statutes in the past half-century that address the recognition of foreign judgments. In 1962 the National Conference of Commissioners on Uniform Law promulgated the Uniform Foreign Money Judgments Recognition Act (UFMJRA), ${ }^{14}$ which came to be adopted by over

Ending Judgment Arbitrage: Jurisdictional Competition and the Enforcement of Foreign Money Judgments in the United States, 54 HARv. INT'L L.J. 459 (2013).

7 Born \& Rutledge, supra note 2, at 1069-70.

8 Convention on Choice of Court Agreements, June 30, 2005, 44 L.L.M. 1294. For a thorough summary and analysis of this convention, see Gary Born, The Hague Convention on Choice of Court Agreements: A Critical Assessment, U. PA. L. Rev. (forthcoming) (manuscript on file with author).

9 Born \& Rutledge, supra note 2, at 1070. For further discussion of the Hague Convention proposal and others, notably the federal judgments legislation proposed by the American Law Institute in 2005, see $i d$. at 1075-76. The failure of the United States to ratify the Hague Conventions has been attributed to the fear that ratification would federalize a topic traditionally governed almost entirely by state law, and that states, rather than the federal government, have usually taken the lead in responding to foreign judgment recognition issues. See Ronald A. Brand, Of Magnets and Centrifuges: The US and EU Federal Systems and Private International Law (December 2019), https://ssrn.com/abstract=3505601. In 2019 the Convention on the Recognition and Enforcement of Foreign Judgments in Civil or Criminal Matters was concluded by the Hague Conference on Private International Law, https:/www.hcch.net/ en/instruments/conventions/full-text/?cid $=137$.

10159 U.S. $113(1895)$.

11 Id. at 202-03, 227-28.

12 BORN \& RUTLEDGE, supra note 2, at 1072; S.I. Strong, Recognition and Enforcement of Foreign Judgments in U.S. Courts: Problems and Possibilities, 33 Rev. LiT. 45, 58-59 (2014). One exception to the generalization in the text is that few American states insist upon the reciprocity factor being satisfied. For a thorough and skeptical appraisal of the use and impact of this factor, see John F. Coyle, Rethinking Judgments Reciprocity, 92 N.C. L. Rev. 1109 (2014).

13 Strong, supra note 12, at 59-65 (discussing law followed by federal courts in federal question and diversity cases).

14 Uniform Foreign Money Judgments Recognition Act-UFMJRA (Unif. Law Comm'n 1962), http:// www.uniformlaws.org. 
thirty states. ${ }^{15}$ Inspired by the Hilton criteria, under the UFMJRA foreign judgments were presumptively entitled to recognition, subject to several mandatory and discretionary exceptions. Those exceptions focus on various attributes of the foreign litigation, including unfairness, lack of personal or subject-matter jurisdiction, lack of notice, fraud, inconsistent judgments, violation of a forum selection clause, or contravening public policy. ${ }^{16}$ To update and clarify the UFMJRA, the uniform law commissioners in 2005 promulgated the Uniform Foreign-Country Money Judgments Recognition Act (UFCMJRA), ${ }^{17}$ which has come to be adopted by twenty-five states; ten states still follow the UFMJRA. ${ }^{18}$ The UFCMJRA largely replicates the prior provision, but addresses and clarifies other procedural and substantive exceptions to recognition..$^{19}$ The remaining states follow common-law comity principles..$^{20}$

What is the significance of this body of state law? Some argue "that foreign judgments are often recognized and enforced in the United States, but they receive much more scrutiny in U.S. courts than the judgments of sister states, especially on public policy and procedural adequacy grounds."21 Thus, Christopher Whytock argues that "it is not unfair to characterize ... the US [as] increasingly sceptical about a multilateral private international law approach that favours the enforcement of foreign judgments." ${ }^{22} \mathrm{He}$ contrasts this to developments in the European Union (EU), which have made judgments in the courts of EU members increasingly enforceable in the courts of other EU members. ${ }^{23}$ Nonetheless, Ronald Brand has argued that the legacy of Hilton is that American courts are on the whole "very receptive" to enforcing foreign judgments. ${ }^{24}$ Perhaps both of these characterizations can be true: being subject to greater scrutiny does not necessarily lead to fewer foreign judgments being enforced.

State law in the United States almost entirely governs foreign judgment recognition, and what little relevant federal law there is places limits on such recognition. Most

15 Born \& RutLedge, supra note 2, at 1073.

16 Id.

17 Uniform Foreign-Country Money Judgments Recognition Act-UFCMJRA, 13 U.L.A.5 (Supp. 2006), http://www.uniformlaws.org.

18 Born \& Rutledge, supra note 2, at 1073 n.54; Paul George, Facilitating Money Judgment Enforcement Between Canada and the United States, 72 HAstings L.J. 99, 107 (2020).

19 For discussion of the passage of the UFCMJRA and of the additional exceptions to foreign judgment recognition, see Shill, supra note 6, at 491-501; Strong, supra note 12, at 67-68; Christopher Whytock, Faith and Skepticism in Private International Law: Trust, Governance, Politics, and Foreign Judgments, 2014 Erasmus L. Rev. 113, 117 (Nov. 2014).

20 Ronald A. Brand, Fed. Judicial Ctr., Recognition and Enforcement of Foreign Judgments 11 (2012); Strong, supra note 12, at 68-69.

21 Brilmayer, supra note 6, at 545. See also Samuel P. Baumgartner \& Christopher A. Whytock, Enforcement of Foreign Judgements, Systematic Calibration, and the Global Law Market, 23 THEORETICAL INQUIRIES L. 119 (2022) (empirical study of recognition and enforcement of foreign judgments in U.S. Courts from 2000-2017).

22 Whytock, supra note 19, at 118.

23 Id. at 113-15 (discussing developments in EU law).

24 Ronald A. Brand, The Continuing Evolution of U.S. Judgments Recognition Law, 55 Colum. J. TransNAT'L L. 277, 282 (2017). See also Maggie Gardner, Parochial Procedure, 69 STAN. L. Rev. 941, 1003-06 (2017) (similarly arguing that nonrecognition of foreign judgments by American courts is the exception, not the rule). 
notably, in 2010 Congress passed the Securing the Protection of our Enduring and Established Constitutional Heritage (SPEECH) Act, ${ }^{25}$ which places limits on the enforcement of foreign judgments in libel cases in American courts. Prior to the passage, United States media companies and others had become increasingly concerned with Americans being sued for defamation in foreign countries, where it was typically easier to prevail in such cases, in contrast to the stringent protections for libel defendants frequently available under U.S. law, especially under the First Amendment to the U.S. Constitution. ${ }^{26}$ The SPEECH Act provides that a federal or state court "shall not" enforce a foreign judgment in a defamation case, where the defamation law applied by the foreign jurisdiction does not provide "as much protection" as American law. ${ }^{27}$

Whether it has a robust effect in practice or not, what are the rationales for the greater scrutiny of foreign judgments? The traditional ones are that the legal systems of sister states are more alike as compared to the disparate systems of other nations, and that the underlying judgments sought to be enforced are subject to review in the appellate systems of other states, and potentially in the U.S. Supreme Court. ${ }^{28}$ Similarly, longstanding respect for state sovereignty in many legal spheres, and comity between states, suggests more amenability to enforcing sister-state judgments than those of foreign countries. State courts are more likely to be asked to enforce sister-state judgments, as compared to those of foreign countries, and thus might be more amenable to notions of reciprocity for the former. ${ }^{29}$ Still, others wonder whether the distinction "merely reflect[s] parochialism or unspoken distrust of foreign legal systems." 30

\section{The Law Market Model and Recognition of Foreign Judgments}

Modern theories to resolve conflict-of-laws issues by American courts are dominated by what can be called public law models. These models typically focus on identifying

25 Pub. L. No. 111-223, 124 Stat. 2480, codified at 28 U.S.C. $\$ \$ 4101-05$.

26 See John B. Bellinger, III \& R. Reeves Anderson, Tort Tourism: The Case for a Federal Law on Foreign Judgment Recognition, 54 VA. J. INT'L L. 501 (2013); Sarah Staveley-O'Carroll, Note, Libel Tourism Laws: Spoiling the Holiday and Saving the First Amendment, 4 N.Y.U. J. L. \& LiberTy 252 (2009).

2728 U.S.C. $\$ 4102$. It might be argued that the SPEECH Act, concerned with limiting recognition on a specific topic, might imply overall receptivity toward foreign judgments in other cases. This argument is not persuasive, since the legislative history of the SPEECH Act clearly shows it was largely the result of lobbying by large media companies and their lawyers and supporters. See Elizabeth J. Elias, Note, Nearly Toothless: Why the SPEECH Act Is Mostly Bark, With Little Bite, 4o HofsTra L. Rev. 235, 253-61 (2011) (documenting such support in testimony before Congress and in other ways). Hence it is better viewed as a narrow, interest group-driven exception to the rule of Congressional reticence on foreign judgment recognition and deference to the states.

28 Arthur T. von Mehern \& Donald T. Trautman, Recognition of Foreign Adjudications: A Survey and Suggested Approach, 81 Harv. L. Rev. 1601, 1607 (1968).

29 See generally Lea Brilmayer, Conflict of Laws 187 (2d ed. 1995) (discussing game theory and reciprocity regarding judgment recognition).

30 Born \& RutLedge, supra note 2, at 1146. 
and sometimes weighing the perceived regulatory and other interests of the states connected to the parties and their legal dispute, to determine which state's law applies. The modern choice-of-law theories adopted by most American state courts, such as the Restatement (Second) of Conflict of Laws, promulgated by the American Law Institute in 1971, or interest analysis and its variations, are examples of the public law model. ${ }^{31}$

An alternative private law model, as Ralf Michaels has usefully summarized, "focuses on individuals and individual interest," where the "goal is either efficiency or the maximization of global social welfare, understood as the sum of the utilities of all individuals worldwide. The main way to achieve these goals is private, contractual choice of law."32 Modern public law models are not oblivious to these arguments and frequently attempt to take them into account. ${ }^{33}$ Thus, the Second Restatement enforces contractual choice-of-law clauses, at least when the choice is reasonable and does not contravene some strong public policy of the jurisdiction whose law would otherwise apply. ${ }^{34}$ Likewise, most American states now enforce forum selection clauses, permitting parties to ex ante designate the forum for any legal dispute they may have, at least when the choice is reasonable..$^{35}$

Nonetheless, advocates of a private law model have taken it one step further with the law market model, which places heavy emphasis on the parties choosing their own law ex ante with few if any restrictions, and more generally posits that "all choice of law rules should mimic the result of a hypothetical choice-of-law agreement

31 Symeon C. Symeonides, Choice of Law in the American Courts in 2019: Thirty-Third Annual Survey, 68 AM. J. Compar. L. 235, 258-59 (2020) (depending on whether contract or torts cases are considered, up to 40 of the 50 states follow modern choice-of-law theories; the remaining states follow the older, territorially based vested rights approach embodied in the first Restatement of Conflict of Laws (1934)).

32 Ralf Michaels, Economics of Law as Choice of Law, 71 LAw \& ConTEMP. Probs. 73, 79 (Summer 2008) (footnotes omitted). As sources cited by Michaels discuss, e.g., Andrew T. Guzman, Choice of Law: New Foundations, 90 GEO. L.J. 883, 894-99 (2002), focusing on the maximization of global welfare is a complex inquiry, combining the utilities of individuals within and across different jurisdictions, as well as consideration of the effects on third parties. A full exploration of these considerations is beyond the scope of the present Article.

33 Michaels, supra note 32, at 85 ("A combination of private and international aspects is of course common in choice-of-law doctrine.")

34 Restatement (Second) Conflict of Laws $\$ 187$ (1971).

35 Born \& Rutledge, supra note 2, at 452-56; Michael E. Solimine, Forum-Selection Clauses and the Privatization of Procedure, 25 CoRnell INT'L L.J. 51 (1992) [hereinafter Solimine, Forum-Selection Clauses]. See also Hannah L. Buxbaum, Conflict of Economic Laws: From Sovereignty to Substance, 42 VA. J. INT'L L. 931, 958-62 (2002) (tracing the rise of party autonomy in conflicts of laws to U.S. Supreme Court decisions in the 1970 and 1980 os enforcing choice-of-forum and choice-of-law clauses which enabled waiver of federal regulatory statutes). There is a considerable literature skeptical of party autonomy in private international law and other contexts, e.g., William J. Woodward, Jr., Contractual Choice of Law: Legislative Choice in an Era of Party Autonomy, 54 SMU L. Rev. 697 (2001). See generally Michaels, supra note 32, at 97-98 (discussing objections to party autonomy); Michael E. Solimine, The Law and Economics of Conflict of Laws, 4 AM. L. \& ECON. REv. 208, 216 (2002) (book review) (same). My purpose is not to engage at length with this literature, but to take the law market model, broadly defined, on its own terms and address whether and to what extent it makes sense to extend that model to foreign judgment recognition. 
between the parties." ${ }^{36}$ In American academic circles, an influential example of the law market model is the collaborative work of Dean Erin A. O'Hara O'Connor and the late Larry E. Ribstein. ${ }^{37}$ The premises of that model are that the most efficient laws come about when consumers are empowered to choose the laws to govern their legal relations, much as they choose other products in a market economy. Public choice critiques undermine the notion that state lawmaking institutions develop the most efficient laws or even ones that in some sense best represent a particular jurisdiction. Rather, the critique goes, many such laws are the product of lobbying by rent-seeking interest groups, influencing information-challenged legislators. The model assumes that states can and will compete in a market of laws to provide choices to consumers. ${ }^{38}$

O'Connor and Ribstein acknowledge that the law market can be subject to market failure. Unsophisticated consumers may be unable or unwilling to fully research the menu of laws they may choose. It may not always be clear whether the market of states is generating efficient laws, i.e., whether there is a race to the bottom or to the top among those jurisdictions. Moreover, robust enforcement of choice-of-law clauses has the potential to severely undermine a state's regulatory interests. Among the ways to ameliorate these concerns is to provide that state legislatures can make their laws nonwaivable, and hence not avoidable in choiceof-law clauses, by explicitly placing mandatory language in the laws. ${ }^{39}$ Another way could be to mandate, by law, that the options made available to consumers be clear in the contractual papers or limited to a menu. ${ }^{40}$

How can the law market model address the topic of the present Article? If persons can ex ante pick the substantive and procedural law that might affect them, and the forum where a legal dispute can be litigated, why not extend it to the legal regime governing recognition and enforcement of judgments? Yet the literature on the law market model says relatively little on extending the model to this issue.

36 Michaels, supra note 32, at 79. As Michaels points out, the law market model shares some attributes of the vested rights model exemplified by the first Restatement of Conflict of Laws (1934), since the latter emphasized that rights to bring suit vest in individuals, as mainly determined by the law of jurisdictions where the events giving rise to the dispute took place. Id. at 79-82.

37 See Erin A. O’Hara \& Larry E. Ribstein, The Law Market (2009); Erin A. O’Hara \& Larry E. Ribstein, From Politics to Efficiency in Choice of Law, 67 U. CHI. L. REv. 1151 (2000). Another influential argument in favor of the law market model in this context is Michael J. Whincop \& Mary Keyes, Policy and Pragmatism in the Conflict of Laws (2001).

38 See O'Hara \& Ribstein, supra note 37, at 3-14 (general overview of the law market model); O'Hara \& Ribstein, supra note 37, at 1152-54 (same). When an ex-ante choice of law is not possible or not done, the private law model suggests that choice-of-law rules can be developed to "mimic the result of a hypothetical choice-of-law agreement between the parties." Michaels, supra note 32, at 79 (footnote omitted). This can be accomplished by a rule which "maximize[s] the parties' ability to choose their applicable law by controlling the location of their activities." O'Hara \& Ribstein, supra note 37, at 1188 (footnote omitted). Examples could be the place of contract offer or acceptance in contract cases, or the place of negligent conduct or injury in personal injury torts cases. Id.

39 O'HARA \& RibSTEIN, supra note 37, at 208-13 (arguing that the burden should be placed on legislatures to expressly make laws mandatory and nonwaivable by choice-of-law clauses); O'Hara \& Ribstein, supra note 37 , at $1199-1200$ (same).

40 O'Hara \& Ribstein, supra note 37, at 1186-87; Gisela Rühl, Consumer Protection in Choice of Law, 44 CoRNELl INT'L L.J. 569 (2011). 
For example, O'Connor and Ribstein, correctly observing that federal law does not require recognition of foreign judgments, suggest that parties may opt ex ante for arbitration, since many nations will enforce arbitral awards in certain circumstances. ${ }^{41}$ But they do not explicitly consider the possibility of parties contractually selecting a body of law on judgment recognition, or simply waiving the requirements of those laws in the first instance. ${ }^{42}$

Michael J. Whincop and Mary Keyes have advanced choice-of-law arguments that, similarly to O'Connor and Ribstein, rely on game theory ${ }^{43}$ and private law models to analyze the actions of states and individuals in the choice-of-law context. They contend "that the parties can indirectly contract for recognition through the expedient of a jurisdiction clause." ${ }^{44}$ By this they mean that via a forum selection clause, the parties can strategically choose a forum that will render a judgment, which may in turn affect the ease or difficulty of enforcing that judgement, depending on the recognition regimes of other jurisdictions..$^{45}$

American law does acknowledge one way in which contractual choice can in effect waive requirements for recognition of judgments. The cognovit note or judgment permits a debtor to agree ex ante that, upon default, a judgment on a debt can be executed without further notice or hearing, where the debtor agrees that an attorney can be assigned to receive notice. ${ }^{46}$ The cognovit judgment has deep roots in Anglo-American jurisprudence ${ }^{47}$ and the United States Supreme Court has held that courts enforcing such provisions are not "per se, violative of Fourteenth Amendment due process." ${ }^{38}$ Nonetheless, the cognovit judgment has had a controversial career in American law. Concerns have long been raised about the unfairness of entering a judgment against a debtor without traditional opportunities for notice or a hearing. ${ }^{49}$ Others argue that cognovit provisions should be allowed as part of the contractual negotiations between creditors and debtors, with such provisions being one price for easier access to the loan market. ${ }^{50}$ Only a small number of American states specifically authorize the device; other states prohibit its use for

41 O'HARA \& Ribstein, supra note 37, at 95-96.

42 Gary Born and Bo Rutledge raise the possibility of contractual waiver of judgment recognition requirements, without stating whether and to what extent it might be permitted. See BorN \& RUTLEDGE, supra note 2 , at 1134 ("Can parties prospectively waive their defenses to the enforceability of a judgment? ... How, if at all, do considerations of prospective waiver in the judgment enforcement context differ from those in other contexts (like the enforceability of a forum selection clause or an arbitration clause)?").

43 See generally Michael E. Solimine, Game Theory and Private International Law, in 1 ENCYCLOPEDIA OF Private International LaW 830 (Jürgen Basedow et al. eds., 2017).

44 Whincop \& Keyes, supra note 37, at 159.

45 Id. See also Michael Whincop, The Recognition Scene: Game Theoretic Issues in the Recognition of Foreign Judgments, 23 Melb. U. L. Rev. 416, 437-38 (1999) (parties might contract on judgment recognition in other ways, such as committing that judgments issued by certain courts or governed by certain law would not be subject to recognition).

46 Charles Auerbach, Cognovit Notes: Should They Be Abolished?, 80 Coм. L.J. 97, 97 (1975).

47 Id. at 97-98.

48 D. H. Overmyer Co., Inc. v. Frick Co., 405 U.S. 174, 187 (1972).

49 Id. at 177 n.4; Dan Hopson, Jr., Cognovit Judgments: An Ignored Problem of Due Process and Full Faith and Credit, 29 U. CHI. L. Rev. 111, 120 (1961).

50 Auerbach, supra note 46, at 100-01; Hopson, supra note 49, at 121-23. 
small loans or in consumer sales. ${ }^{51}$ Despite the controversy, the general rule is that cognovit judgments entered in one state are enforceable in another under the Full Faith and Credit Clause. ${ }^{52}$

The law on cognovit judgements does not directly address the recognition of foreign judgments, but it suggests by analogy that parties can through forum-selection or choice-of-law clauses, or both, ex ante waive or select judgment recognition regimes. That analogy was employed in the foreign judgment context in the high-profile Lloyd's of London insurance litigation two decades ago. A thorough summary of that complicated litigation is unnecessary here. ${ }^{53}$ Suffice it to say that the storied Lloyd's was not an insurance company as such, but managed an association or syndicate of insurance companies. In the 1980 s and 1990 s the syndicate came to suffer huge underwriting losses, due to coverage of asbestos and pollution claims, and in response Lloyd's entered into new contracts with the members of the syndicate. Those contracts had, among other things, clauses that selected British courts and law as the forum and law to govern their disputes. The contracts also had a "pay now, sue later" clause, which required the syndicate member "to pay the amount claimed by Lloyd's up front, without any setoff or counterclaim of any kind, without seeking any stay of execution or injunction against enforcement, and consented to the immediate enforcement of any judgment obtained by Lloyds." ${ }_{4}$ This was the equivalent of a confession of judgment provision. ${ }^{55}$

Litigation over these provisions against American members of the syndicate took place in the United States. One of the cases was brought, perhaps not coincidentally, in federal court in Illinois, one of the few jurisdictions that will enforce a cognovit note, albeit not in the consumer context. ${ }^{56}$ That case, Society of Lloyd's v. Ashenden, ${ }^{57}$ upheld the provisions in question in a notable opinion by Judge Richard A. Posner. That litigation began on the heels of failed efforts in American courts to defeat the enforcement of the choice-of-British forum clauses. ${ }^{58}$ Suit was then brought by Lloyds to enforce large judgments from British courts in Illinois, under Illinois' version of the UFMJRA. The defendants attacked those judgments as procedurally deficient, and thus falling under the exception of the UFMJRA which states that a foreign judgment is unenforceable if it "was rendered under a system which does

See D.H. Overmyer, 405 U.S. at 177-78 (surveying state laws); Hopson, supra note 49, at 126-31 (same). With rare exceptions, states enforce cognovit notes filed as judgments from other states. See PetER HaY, Patrick J. Borchers, Symeon C. Symeonides \& Christopher A. Whytock, Conflict of Laws 1402 n.152 (6th ed. 2018). See, e.g., Capital Partners Network OT, Inc. v. TNG Contractors, LLC, 2020 WL 6708232 (Tenn. App. 2020); Fiore v. Oakwood Plaza Shopping Center, Inc., 585 N.E.2d 364 (N.Y. 1991).

For an excellent and detailed analysis of the Lloyd's litigation, see Courtland H. Peterson, Choice of Law and Forum Clauses and the Recognition of Foreign Country Judgments Revisited Through the Lloyd's of London Cases, 6o LA. L. Rev. 1259 (2000).

Id. at 1266 (emphasis in the original).

Id. at 1261 .

Id. at 1277; Hopson, supra note 49, at 1215.

Society of Lloyd's v. Ashenden, 233 F.3d 473 (7th Cir. 2000).

Id. at 475 . 
not provide impartial tribunals or procedures compatible with the requirements of due process of law." 59

The court rejected that argument, primarily on the basis that the exception by its terms only focused on the entire British legal system, not on the specific litigation, and that only fundamental fairness was required, which was satisfied in this case. ${ }^{60}$ In the course of reaching that conclusion, the court noted the analogy to cognovit judgments. The defendants argued that the "pay now, sue later" improperly waived their rights to procedural due process as determined by American law. The court disagreed, observing that procedural due process rights can be waived under American law. Thus, the court continued, this case was brought "within the rule of D.H. Overmyer ... which upheld against a due process challenge similar to that mounted by the [syndicate members] in this case the enforcement of a cognovit note...."' ${ }^{1}$

Ashenden did not directly involve the recognition of a foreign judgment. Rather, in English courts there was no trial on the merits, but immediate enforcement of the assessment, given the "pay now, sue later" clause and other provisions of the contract. ${ }^{62}$ Thus, it was closely akin to a cognovit note, but it does so in the context of applying (if narrowly) the fairness and public policy exceptions of the UFMJRA. ${ }^{63}$ It does not address any contractual effort to waive or modify the UFMJRA itself or similar laws, to select which states' laws apply. Whether such contractual waiver or selection is possible or desirable is the subject of the following parts of this Article.

\section{Foreign Judgment Recognition Statutes As Mandatory LaW AND THE Limits of The LaW Market Model}

There is a large literature on whether and to what extent parties might contract around otherwise applicable regulatory statutes in the choice-of-law context, that is, whether these laws are mandatory or not. ${ }^{64}$ In its most robust form, a law market model might suggest that all regulatory laws can be contractually waived ${ }^{65}$ Recall that most advocates of the model do not take this view. Rather, they acknowledge the regulatory interests of states and argue that some laws are mandatory and nonwaivable in some circumstances.

$59 \quad I d$. at 476.

60 Id. at $476-80$.

$61 \quad$ Id. at 479.

$62 I d$. at 478 (distinguishing the "merits" and "collection" phases of the case); Peterson, supra note 53, at 1266-67.

63 For discussions of how Ashenden and other cases apply those provisions, see BoRn \& RUTLEDGE, supra note 2 , at $1142-47$.

64 See, e.g., Hannah L. Buxbaum, Mandatory Laws in Civil Litigation: Status of the Doctrine Post-Globalization, 18 Am. Rev. Int'L Arb. 21, 30-35 (2007).

$65 I d$. at 34 . 
Thus, O'Connor and Ribstein argue that regulatory statutes are presumptively waivable unless they specifically state that they are not waivable by a choice-of-law clause or otherwise. They defend this super-mandatory interpretative canon for three reasons: it requires the regulatory state to make this policy choice, rather than leave it as an interpretative decision to the courts of that state or another; it provides predictability and clarity; and it forces pro-regulatory interest groups to pay for the presumably extra lobbying to craft legislation "that will trump contractual choice of law." ${ }^{36}$ They add that even a super-mandatory rule should not trump party choice unless the party protected or regulated by the law resides in the regulating jurisdiction. The additional requirement is to ensure that the regulating jurisdiction has an interest "sufficiently large to justify interfering with the operation of the law market[,]" and "encourages people and firms to avoid regulation if they want" by voting with their feet. ${ }^{67}$

How does this proposed regime apply to foreign judgment recognition statutes in the American states? The initial answer is that none of the state recognition laws discussed in this Article can be labeled as super-mandatory. There is no mandatory language forbidding waiver, much less specifically referencing choice-of-law clauses, in the UFMJRA or UFCMJRA, or in the commentary accompanying those uniform laws. None has been added by the states which adopted those laws. To my knowledge, even those states which have adopted neither of these Acts adopted legislation which separately forbids waiver of foreign judgment recognition requirements. ${ }^{68}$

While this conclusion might seem to easily follow from a straightforward application of the law market model, as espoused by O'Connor and Ribstein, it might be resisted for several reasons. While the text of the uniform laws has no express language regarding waiver, they do refer to the courts of states not having authority to enforce a foreign judgment, if certain criteria are met. ${ }^{69}$ This might suggest that the prohibitions are akin to restrictions on the subject-matter jurisdiction of American courts, which have long been considered as non-waivable by the parties and the courts themselves. Courts may also be reluctant to embrace such a reading of the uniform laws, since the enforcement of a waiver will likely benefit a foreign creditor (who brought the suit in the other nation) to the detriment of an American and probably local judgment-debtor. ${ }^{70}$ Finally, as noted with regard to the Ashenden litigation, many judges might easily analogize such contractual waivers

66 O'Hara \& Ribstein, supra note 37, at 209.

$67 I d$. at 211.

68 The same conclusion obtains for the proposed ALI statute and the Hague Convention, see supra note 9, and the SPEECH Act, supra note 27. Granted, the lack of anti-waiver language in these provisions may well be due to legislative assumptions that the law market simply does not operate regarding judgment recognition. If so, little or perhaps no weight should be given to the lack of such language, i.e., it should be assumed that the legislature intended the provisions to be mandatory. These points are especially weighty when interpreting the UFMJRA, promulgated in 1962 when there was less widespread use and enforcement of choice-of-law and choice-of-forum clauses. On the other hand, these clauses were in much more use by 2005 when the UFCMJRA was promulgated. The lack of anti-waiver language in the latter can be given more weight under a law market model.

69 E.g., UFCMJRA, supra note $17, \$ \$ 4-5$ (“A court of this state may not recognize ...").

70 Whincop \& KeYEs, supra note 37 , at 157. 
to cognovit notes, which have a tortuous history in American jurisprudence. In some quarters, they are controversial enough regarding parties from the United States. ${ }^{71}$ They would be more controversial still if they in effect came by way of the legal authority of a foreign country.

Such resistance to waiver of foreign judgment recognition statute requirements might occur even while other aspects of the law market model are embraced (e.g., choice-of-law and forum-selection clauses). Thus, American state law, on its face if not necessarily in application, has more hurdles to enforcing foreign judgments as compared to, say, the members of the EU among themselves. Writing in 2014, Christopher Whytock discussed several reasons for this dichotomy. There can be said to be more mutual trust within the EU as compared to the United States and the rest of the world. ${ }^{72}$ By another account, the EU is increasingly focused on the governance functions of private international law, while the United States largely remains focused on how private international law affects individual rights, particularly those of judgment debtors. ${ }^{73}$ Finding these rationales inadequate or question-begging, Whytock concludes that raw politics accounts for many of the differences between the EU and the United States. The foundational treaties of the EU, he argues, establish a political mandate to facilitate enforcement of judgments within the EU to achieve a common market. In contrast, he says, there is no parallel political mandate in the United States. The issue is almost entirely decentralized among the states. "But," he suggests, "the politics are there, and they push in the other direction." ${ }^{\prime 4} \mathrm{He}$ notes that the United States Chamber of Commerce and other interest groups have advocated for case-specific exceptions to recognition of foreign judgments. ${ }^{75}$ This is no surprise, since American businesses are "especially likely to have substantial assets in the U.S. that can be pursued by judgment creditors in enforcement actions." 76

The political explanation can be taken even further by expanding to broader accounts of legal culture. As has already been emphasized, it is one thing to enforce a sister-state judgment. But enforcing a judgment entered by a court in a foreign country may be seen by some as undermining the sovereignty of an American

71 I am unaware of any recent study, empirical or otherwise, of the use and enforceability of cognovit judgments in American courts. An admittedly now dated study reports that due to their favorable laws, Illinois, Pennsylvania and Ohio "produce the overwhelming bulk of cognovit judgments taken in the United States." Hopson, supra note 49, at 115 (footnote omitted). For a recent enforcement of an Ohio cognovit judgement by the Ohio Supreme Court, see Sutton Bank v. Progressive Polymers, L.L.C., 161 Ohio St.3d 387, 163 N.E.3d 546 (2020).

72 Whytock, supra note 19, at 117-20. Another reason for the apparent reluctance of state courts and legislatures to recognize foreign judgments may be the lack (real or perceived) of reciprocity of American judgments in foreign courts. That is, American courts may be reluctant to enforce foreign judgments without guaranteed reciprocation by the other side. This may be a factor even though a majority of states do not consider reciprocity when considering the enforcement of a foreign judgment. See supra note 12 .

73 Whytock, supra note 19, at 120-22.

$74 \quad$ Id. at 124.

75 He gives as an example, id. at 124 n.101, the Chamber's support for the SPEECH Act, see supra notes 25-27 and accompanying text.

76 Id. at 124. 
state. That is, judgment enforcement and recognition can be seen as the last tool available to the enforcing state to influence the effect of cases litigated outside the United States. They would be the last instance to ensure that foreign judgments do not violate the legitimate interests of the citizens of the enforcing state. ${ }^{77}$

Broader cultural norms may also be at work. By common consensus there is a longstanding strain of xenophobia in American public affairs, ${ }^{78}$ and it has not escaped application in the American legal system. Empirical studies demonstrate that, to varying degrees, parties from foreign countries, or those perceived to be associated in some way with foreign countries, face difficulties for that reason in receiving fair adjudication in American courts. ${ }^{79}$

The regime of foreign judgment recognition in the American states has been described, at least in part, as a product of xenophobia. ${ }^{80}$ One study was premised on the notion that, broadly speaking, adoption of the UCMJRA after 1962, and of the UFCMJRA after 2005, made it easier to enforce a foreign judgment. The study found that such adoption by states was correlated with indicia of greater tolerance in the adopting jurisdictions, such as the number of art museums and public opinion in support of gay rights or immigrants. ${ }^{81}$ One could also assume that states with greater international economic engagement would be "more open to the enforcement of foreign judgments as a means to facilitate commercial exchange." 82 Perhaps surprisingly, though, the study found only weak support for the latter assumption. ${ }^{83}$ The researchers granted limits to their study, noting for example that cultural attitudes are difficult to quantify, and that some argue the UFCMJRA made it more difficult, not less, to enforce a foreign judgment as compared to the UCMJRA. ${ }^{84}$ Nonetheless, the study concluded that hostility "toward foreign people or cultures ... correlates with aversion to foreign judgments and reluctance to make their enforcement easier." 85

77 Thanks to an anonymous reviewer for suggesting this point.

78 See Erika Lee, America for Americans: A History of Xenophobia in the United States (2019).

79 See, e.g., Utpal Bhattacharya, Neal Galpin \& Bruce Haslem, The Home Court Advantage in International Corporate Litigation, 50 J. L. \& EcON. 625 (2007) (American corporations less likely to lose as compared to foreign companies); Clermont \& Eisenberg, supra note 1 (revisiting various studies and suggesting caution in drawing cultural conclusions); Kimberly A. Moore, Xenophobia in American Courts, 97 Nw. U. L. REv. 1497 (2003) (foreigners won at lower rate in patent cases). But see Kevin M. Clermont \& Theodore Eisenberg, Xenophilia in American Courts, 109 HARv. L. Rev. 1120 (1996) (study of federal district court cases from 1987 to 1994 showed higher win rates for foreigners in civil cases as compared to domestic litigants).

80 Asif Efrat \& Abraham L. Newman, Cultural Intolerance and Aversion to Foreign Judgments in the American States, 9 AsiAn J. L. \& ECON. 1 (2018).

$81 \quad$ Id. at 12.

82 Id. at 9.

83 Id. at 12.

$84 \quad I d$. at $4,7$.

$85 I d$. at 12. Yet another example of aversion to foreign law, albeit one that does not map directly on hostility to foreign judgments, is the large number of states that have adopted laws that purport to prohibit court reliance on Sharia or other foreign law. See Martha F. Davis \& Johanna Kolb, Oklahoma and Beyond: Understanding the Wave of State Anti-Transnational Law Initiatives, 87 IND. L.J. Supp. 1 (2011). 
In light of these formidable political and cultural hurdles, it may seem unlikely that American courts will readily adopt a regime that permits contractual waiver of foreign judgment recognition statutes. A somewhat more likely step might be permitting parties to select a particular state's recognition law, via a choice-of-law clause. Still, whether the hurdles are formidable or not, is it worth the effort to convince policymakers of this change? The following and final part of this Article reconsiders the normative case for applying the law market model to foreign judgment recognition.

\section{Integrating Foreign Judgment Recognition AND The LaW Market Model}

The previous parts of this Article suggested that application of the law market model leads to the conclusion that foreign judgment recognition statutes can be ex ante waived or selected by contract, but that contemporary political and cultural reasons make it unlikely that legal institutions in many American states would approve of that step. Despite the latter conclusion, this part of the Article puts to one side the legal and cultural obstacles outlined in the prior part, and revisits the premises of the law market model to advance a normative case that private international law should, at least within certain limits, permit parties to contract around any given state's foreign judgment enforcement regime.

The case for party autonomy in selecting or evading foreign judgment recognition statutes is essentially the same one for enforcing choice-of-law clauses, the central focus of the law market model outlined above. ${ }^{86}$ The Second Restatement of Conflict of Laws promulgated in 1971 enforced choice-of-law clauses, at least when (to generalize) there is some reasonable basis for the parties' choice, or when the law of the chosen state would not undermine an important public policy of the state whose law would otherwise apply. ${ }^{87}$ Many advocates of at least some party autonomy in private international law similarly acknowledge limits on contractual choice: it should not apply when there are information asymmetries between the parties, or third-party externalities. Most advocates also acknowledge interests of the state whose law would otherwise apply by allowing for that state to assert some public policy exception, ${ }^{88}$ as already noted, O'Connor and Ribstein limit that exception to when the state law expressly forbids waiver by a choice-of-law clause.

There is no a priori reason why choice-of-law clauses, within these bounds, cannot include waiver or selection of foreign judgment recognition statutes. One objection might be that such coverage includes procedural in addition to substantive law issues. There is a longstanding debate whether choice-of-law clauses (or waiver

\footnotetext{
86 O'Hara \& Ribstein, supra note 37, at 206-14.

87 Restatement (Second) of Conflict of Laws $\$ 187(2)(a-b)(1971)$. For more detailed discussion of this provision and its judicial application, see Brilmayer, supra note 6, at 648-76; Katherine Florey, Substance-Targeted Choice of Law Clauses, 106 VA. L. REv. 1107 (2020).

88 O'Hara \& Ribstein, supra note 37, at 1194; Michaels, supra note 32, at 95.
} 
more generally) should be able to cover the former in addition to the latter. The aforementioned provision of the Second Restatement avoids directly addressing the issue, but some decisions do permit procedural issues to be covered, at least if the choice-of-law clause expressly includes reference to such issues. ${ }^{89}$

Of course, coherently distinguishing between substance and procedure is a longstanding conundrum inside and outside of choice-of-law circles. Ralf Michaels argues that the law market model, whatever its other virtues, has largely avoided directly grappling with, much less resolving, the substance/procedure distinction and issues of characterization more generally. ${ }^{90}$ Fully addressing that debate is beyond the scope of this Article. What can be said is that to the extent that one agrees that at least some procedural issues are fit to be resolved by choice-of-law clauses, legal regimes for foreign judgment recognition should not be excluded.

Consider one recent effort distinguishing types of procedural law that can, or cannot, be waived or changed by the parties. Ronen Avraham and William Hubbard argue that there is a "core" of procedure that parties should not be permitted to alter. This includes "aspects of procedure that are central to the functioning or legitimacy of the courts, such as rules governing the recusal of judges, judicial control over oral arguments and decision-making, and the right to appeal." ${ }^{91}$ Contracting around procedure outside of this core, they continue, should be "invalidated only in limited circumstances, such as when the contract harms third parties or contains unacceptably one-sided terms." ${ }^{2}$ The core-type procedures are typically those concerned with the public perception of and legitimacy of the courts, or those dealing with longstanding norms of reasoned judicial decision-making. ${ }^{93}$

Legal rules concerning the recognition and enforcement of foreign judgments should be considered to fall outside the protected core of procedure. ${ }^{94}$ Those rules, especially for most disputes traditionally within the purview of private domestic or international law, typically do not implicate the legitimacy or decision-making processes of courts. Rather, they concern issues at the tail end of cases, when (at least in theory) the merits of the case have been adjudicated domestically or in a foreign country, and all that remains is to allow a prevailing party to execute on their judgment by an exchange of money. It does not reflect on how the merits were resolved, or on a judgment that might have greater third-party effects (such as an injunction).

How would the suggested legal regime be enforced in this context? This question reflects longstanding discussions of how choice-of-law or forum clauses should be enforced. That is, even if one begins with a law market-based presumption in favor

\footnotetext{
89 BORn \& RUtledge, supra note 2, at 746-47, 758; BRILMAYER, supra note 6, at 657.

90 Michaels, supra note 32, at 91-93 (critiquing O'Connor \& Ribstein, and Whincop \& Keyes on this point).

91 Ronen Avraham \& William H.J. Hubbard, The Spectrum of Procedural Flexibility, 87 U. CHI. L. REv. 883,886 (2020).

Id.

Id. at 891-96.

Whether the analysis advanced here should also apply to intra-state recognition and enforcement of judgments entered in American courts is a topic beyond the scope of this Article.
} 
of the enforcement of such clauses, how does or should a court asked to enforce them determine that they are lawful? The consensus appears to be that the law of the court asked to enforce the clauses applies to determine whether a contract with those clauses is lawful, not self-referencing law found in the contract itself. ${ }^{95}$

A similar analysis should be used in the present context. Current sources of American law (e.g., the uniform acts or state common law dealing with foreign judgment recognition) do not address the waiver issue, so courts could for now develop a common law of contracts to test the legality of contracts that waive or select state judgment enforcement regimes. The principles of comity found in Hilton v. Guyot, still applied in some states and the inspiration for the uniform acts, would be the model. This would permit American state courts to ensure that contracts waiving or selecting foreign judgment recognition law were not the product of unfair bargaining or resulted in improper third-party externalities. ${ }^{96}$

The suggested judicial inquiries would not simply replicate the criteria found in the existing uniform acts. If that were the case, there would be little reason for the entire enterprise of contracting around the strictures of judgment recognition statutes. Instead, the suggested analysis would focus on the fundamentals of contract law: was there a proper offer, acceptance and consent among the contracting parties, and is there evidence of severe information or bargaining power asymmetries? This is the typical inquiry before enforcing a domestic cognovit note ${ }^{97}$ It is also similar to the "reasonableness" inquiries that characterize judicial scrutiny of choice-of-law and forum-selection clauses. ${ }^{98}$ Since the proceedings that led to the judgment were in a foreign country, it is appropriate to subject the legal processes there to some scrutiny, at a high level of generality. The inquiry, like that conducted by Judge Posner in Ashenden, of the country's litigation system as a whole would be a model. If these inquiries are satisfied, the foreign judgment should be recognized and enforced,

95 See Kevin M. Clermont, Governing Law on Forum-Selection Clauses, 66 Hastings L.J. 643 (2015); Tanya J. Monestier, When Forum Selection Clauses Meet Choice of Law Clauses, 69 AM. U. L. Rev. 325 (2019).

96 It can be argued that the enforcement regime suggested here should be restricted to legal disputes where the parties have a preexisting contractual relationship. It would be inappropriate, this argument continues, to expect the parties with no such relationship, such as in many tort cases, to ex ante choose the law or waive American judgment recognition rules. On the other hand, in other tort cases (e.g., medical malpractice; products liability) there is some type of contractual relationship between the parties, which could be the predicate for the sort of waiver advanced here.

97 See D. H. Overmyer Co., Inc. v. Frick Co., 405 U.S. 174, 188 (1972). (suggesting that a cognovit note need not be enforced "where the contract is one of adhesion, where there is great disparity in bargaining power, and where the debtor received nothing for the cognovit provision ..."); Fiore v. Oakwood Plaza Shopping Center, Inc., 585 N.E.2d 364, 368-69 (N.Y. 1991) (inquiry in a decision whether to enforce a cognovit judgement from another state is whether the waiver of rights was voluntary, knowing and intelligent); Capital Partners Network OT, Inc. v. TNG Contractors, LLC, 2020 WL 6708232, * 7-8 (Tenn. App. 2020) (similar analysis).

98 BORN \& RUTLEDGE, supra note 2, at 445-511 (discussing factors that courts consider in determining the enforceability of forum selection clauses); BRILMAYER, supra note 6, at 648-76 (discussing application of factors in the Restatement (Second) Conflict of Laws $\$ 187$ (1971) to enforce choice-of-law clauses). 
notwithstanding the precise procedures found in the statutory or common law of that state dealing with the topic. ${ }^{99}$

As previously mentioned, the ex-ante choice suggested here can take place either by explicit waiver during the contractual relationship, or by a choice-of-law clause, where the recognition law of a particular jurisdiction is selected. ${ }^{100}$ These options can be analyzed in different ways from the perspective of the law market model. When enforcement of a foreign judgment is sought, ostensibly a court has endorsed the fairness of the proceedings and the rules applied. Similarly, enforcing a choice-oflaw clause permits the parties to pick a body of recognition law from a jurisdiction (e.g., an American state) that presumably has, by legislation or otherwise, devoted considered attention to the topic. The validity of a contract with such a choice-of-law clause presumably has, or could been, adjudicated in the foreign tribunal.

In contrast, permitting outright waiver of any recognition laws arguably raises more difficult issues. Enforcing such a clause prioritizes party autonomy, but allows the parties to create the rules, the application of which no state or court has endorsed. It raises the distinction between that and waiving procedural law discussed above. Ultimately, given the similarity to the controversial cognovit note, the latter option may be less likely to be adopted by the American legal community.

The law market model as presented here assumes that there is or can be a market among the American states that have differing laws on when and how a foreign court judgment can be enforced. This assumption has been challenged by Ronald Brand and Gregory Shill, who have suggested that state legislatures have generally left intact the common-law principles on foreign judgement recognition, ${ }^{101}$ and further have not competed to supply "superior law in this area as they do in other areas of

99 American judges may consider themselves to be ill-equipped and thus reluctant to undertake a fairness inquiry of another nation's legal system as a whole, much less that for the particularities of a specific legal dispute. Indeed, such reluctance may be especially appropriate as it concerns judgment recognition. See Society of Lloyd's v. Ashenden, 233 F.3d 473, 477 (7th Cir. 2000). ("a retail approach," examining the fairness of any particular litigation, would "be inconsistent with providing a streamlined, expeditious method for collecting money judgments rendered by courts in other jurisdictions - which would in effect give the judgment creditor a further appeal on the merits.") But see BoRn \& RutLEDGE, supra note 2, at 1144 (suggesting that American "judicial inquiry into the fairness of an entire legal system [is] more likely to raise comity and separation of powers concerns than inquiry into the fairness of a particular legal proceeding[.] ... [a] judicial body [might be] better equipped to judge the fairness of a particular proceeding (as appellate courts frequently do) than the fairness of an entire legal system[..]") That said, one way to deal with this reluctance would be for American courts to enforce judgments from a predetermined list of countries that have been deemed to have fair procedures, as determined by treaty or another agreement, or by state legislatures or courts. A corollary of that suggestion would be to permit waiver or choice of American state judgment regimes from adjudications in countries on that predetermined list. For a useful discussion of the opportunities and challenges facing American courts when evaluating foreign legal systems in general, and foreign judgments in particular, see Zachary D. Clopton, Judging Foreign States, 94 WASH. U. L. REv. 1, 39-44 (2016).

100 I assume that the parties, via a choice-of-law clause, would be choosing among the American states. It would also be possible, though create additional complications, to consider such clauses choosing the recognition law of a foreign country (e.g., that of the original foreign forum) when a foreign judgment is ought to be enforced in an American court. A full analysis of the latter option is beyond the scope of this Article.

101 Ronald A. Brand, Enforcement of Foreign Money-Judgments in the United States: In Search of Uniformity and International Acceptance, 67 Notre Dame L. Rev. 253, 287-88 (1991). 
the law market." 102 While states might wish "to cater to foreign judgment creditors (perhaps out of a desire to attract litigation to their courts)," they have declined to do so, "since by definition foreign creditors pursuing enforcement actions are seeking to extract wealth from the local economy."103 By the same token, states "do not appear to be competing for the role of safeguarding the assets of prospective judgment debtors, either[.]"104 Moreover, parties and lawyers surveying the current legal regime might find it inhospitable to the arguments raised here, and instead opt for arbitration, with its relatively well-developed standards for enforcement of arbitration awards. ${ }^{105}$

These arguments are not entirely without force, but in my view overstate the case. As previously described, the law on foreign judgment recognition is not monolithic; some states have adopted one or both of the uniform laws, while some have adopted neither. Shill himself observes that there remain numerous differences, large and small, among the American states, since the states frequently modify the uniform acts when they are adopted. ${ }^{106}$ Simply not adopting the newer uniform laws can be seen as a decision to retain a regime more hospitable to the enforcement of foreign judgements. ${ }^{107}$ New York has arguably done this, presumably reflecting its dominance in international business transactions. ${ }^{108}$

Granted, the widespread adoption of uniform laws itself suggests interstate cooperation rather than the presence of a competitive market among the states. ${ }^{109}$ There are variations in those uniform laws, with differences as regards how easy or difficult it is to enforce a foreign judgment. The competition may not be robust but it exists. Consider, too, that different states (and nations) have different law

102 Shill, supra note 6, at 468 (footnote omitted).

103 Id. at $468-69$.

104 Id. at 469. See also Baumgartner \& Whytock, supra note 21, at 124-28 (discussing potential limits on the efficacy of the law market model in the judgment recognition context). Shill further argues that due in part to the possibility of judgment arbitrage, since states "cannot internalize more than a fraction of the benefits that flow from reform to their recognition regimes, their incentives to participate in a competition to be the supplier of the 'best' law (however defined) [is] limited." Shill, supra note 6, at 471.

105 See supra note 41 and accompanying text. Similarly, perhaps many lawyers and parties find the current U.S. legal regime for foreign judgment recognition more or less satisfactory; see supra Part I. Despite its complexities, many foreign judgments can still be enforced under its rules, as recent empirical evidence suggests. See Baumgartner \& Whytock, supra note 21. On the other hand, lawyers may be resigned to the apparent common assumption that state recognition law is mandatory and ex-ante contractual change is futile. Until the full implications of the law market model for foreign judgment recognition are addressed in the U.S. legal community, we may not expect to see the possibilities for contractual choice suggested in this Article.

106 Shill, supra note 6, at 491-501. One example is that not all states insist that a foreign jurisdiction enforce American court judgments in a reciprocal way as a condition of foreign judgment enforcement. Id. at 497.

107 Id. at 495 ("The addition of tribunal-specific fairness defenses in the 2005 Recognition Act makes it easier to for recognition courts to probe the rendering court's respect for due process.").

108 Id. at 469 ("New York, the international business capital of the United States, continues to adhere to the receptive 1962 [UFMJRA], which makes domestication easier than any other recognition statute.") (footnotes omitted).

109 O'Hara \& Ribstein, supra note 37, at 1225-28. 
on analogous matters, such as the enforcement of cognovit judgments, or the enforcement of arbitration awards. ${ }^{110}$

It is also true that states might seem to have little incentive to enter a market for foreign judgment recognition given that foreign creditors are apt to be aided against domestic debtors. Competing in the market may increase the risk of asset flight in the jurisdiction. Surely this is a factor, but it has proven to be not the sole driver of interstate competition on analogous issues. For example, competition for foreign direct investment among nations, or between states in a federation, is driven by numerous legal, economic and other characteristics of the jurisdictions. ${ }^{111}$ Which states such investment is directed to presumably depends, in part, on the legal regimes in those states. A component part is the law of foreign judgment recognition, and it would seem to follow that states could compete in that regard to attract such investment. ${ }^{112}$

Consider also the widespread enforcement of forum-selection and choice-of-law clauses. If applied in an even-handed way, those clauses can direct litigation to, or select law from, places outside the forum. Yet almost all states at least presumptively enforce such clauses. ${ }^{113}$ At the same time, state legislatures frequently have acted in response to pass laws which restrict the enforcement of such clauses, especially regarding consumer contracts. ${ }^{114}$ Similar patterns can take place if a more robust intra-market for interstate competition for foreign judgment recognition were to emerge.

\section{Conclusion}

Party autonomy in private international law, and the related development of the law market model, is widely (though of course not universally) accepted today. Yet it bears emphasis that this is a relatively recent phenomenon. It has only been about five decades since choice-of-forum and choice-of-law clauses have come to

110 Linda Silberman \& Maxi Scherer, Forum Shopping and Post-Award Judgments, in Forum SHOPPING IN the International Commercial Arbitration Context 313 (Franco Ferrari ed., 2013).

111 See Sonal S. Pandya, Political Economy of Foreign Direct Investment: Globalized Production in the Twenty-First Century, 19 AnN. Rev. PoL. SCI. 455 (2016).

112 Efrat \& Newman, supra note 80, at 9 (suggesting that "states that engage with the global economy should be more open to the enforcement of foreign judgments as a means to facilitate commercial exchange."); Antonio F. Perez, The International Recognition of Judgments: The Debate Between Private and Public Solutions, 19 BERKELEY J. INT'L L. 44, 44 (2001) (making similar arguments). That said, I am not aware of any study specifically addressing how companies might take into account the judgment recognition law of different jurisdictions when making investment decisions.

113 See Solimine, Forum-Selection Clauses, supra note 35, at 75-76. A recent empirical study of nearly 900 state court decisions shows, among other things, that about one-quarter of "outbound" forum-selection clauses (i.e., those designating a state other than the forum) are not enforced by courts; John F. Coyle \& Katherine C. Richardson, Enforcing Outbound Forum Selection Clauses, 96 InD. L.J. 1174 (2021). Perhaps it is surprising that non-enforcement is so low, given the assumption that state legal institutions are loath to harm citizens of the state.

114 Cara Reichard, Note, Keeping Litigation at Home: The Role of States in Preventing Unjust Choice of Forum, 129 YALE L.J. 886 (2020). 
be widely enforced in American and other courts. And how party autonomy might impact foreign judgment recognition in the United States has hardly been part of that discussion. The almost universal assumption in the United States appears to be that the common law and state statutes governing foreign judgment recognition are mandatory and not subject to ex-ante selection or waiver.

This Article seeks to further open that discussion to the possibility that party autonomy, and models of domestic and international law markets, can apply to foreign judgment recognition. The arguments advanced are that parties should be able to ex ante select the legal regime that governs the recognition and enforcement of foreign judgments, or in effect waive the requirements of such regimes. The model suggested here also has the benefit, as do other party autonomy regimes, of reducing adjudication costs regarding time and workload, since it suggests a less demanding method of dealing with the recognition of foreign judgments. Despite these benefits, the appropriate limits of party autonomy on this topic remain to the worked out. The present Article does not claim to provide a full model but rather calls for continued attention to how party autonomy and the Law Market model can apply to the recognition of foreign judgments. 
